\title{
有機材料に上る防食技術
}

\author{
青木茂* \\ * 千代田化工建設株式会社 分析・材料技術センター
}

\section{Corrosion Prevension by Organic Materials}

\author{
Shigeru Aoki* \\ * Analysis \& Material Technology Center, Chiyoda Corporation
}

\begin{abstract}
On plastics lining for internal surface of equipment to prevent its corrosion, this paper describes the outlines of their classification, examples of application, properties to be required, selection methods, fabrication procedures, quality control system, inspection methods and diagnosis methods.
\end{abstract}

Key words: plastics lining, application, selection, quality control, inspection, diagnosis

\section{1. 防食用有機材料の種類}

(金属) 防食用の有機材料はいずれも母材である金属を 使用環境の影響から守るための被覆として用いられてい る。な和材料 (materials) を「板・管状等の構造体を形 成するもの」とやや狭義に解すると, 有機化合物であっ てもインヒビターは本稿の対象外となろう。また，有機 材料が 主体となって（単体で）機器を構成する場合の FRP（繊維強化プラスチックス）製品や熱可塑性樹脂の 板・管材及び板と被覆との中間と言っても良い包装用つ ィルムなどは, それらの特性や試験・検査法など考光方 の上で共通点も多い1),2）が，防食用と言うよりはそれら 自身が耐食材料と言うべきで本稿では触れない。

有機材料を用いた防食被覆は, 防せい油・塗装・ライ ニングの三つに大分類されるが，その他に防食テープも 一応の特徴を持ち別の分類を立てて良いかもしれない。 これらは，かなり同一の要素を持うてはいるものの，い ずれも大きな内容のある技術分野であり，本稿では有機 ライニングを主に解説を行うので，防せい油や塗装3》飞 ついての詳細は別書を参照されたい。一応，私見による 三者の特徵を表 1 亿示す。

なお，埋設管に対する塗覆装や，無機ライニングの漏 れ対策用のメンブレンのように，上記分類のいずれかに 入るはずなのに別の用語が定着している業界もある。さ らに，例えばハイビルドやマスチックのように，本来は

* ₹221 横浜市神奈川区守屋町 3-13
表 1 主な防食用有機被覆の特徵

\begin{tabular}{|c|c|c|c|c|c|}
\hline $\begin{array}{r}\text { 有㭖被覆 } \\
\text { の種類 }\end{array}$ & 関連業界 & $\begin{array}{l}\text { 有機系 } \\
\text { 主原料 }\end{array}$ & $\begin{array}{l}\text { 添加· } \\
\text { 充填物 }\end{array}$ & $\begin{array}{c}\text { 主な } \\
\text { 使用琭境 }\end{array}$ & $\begin{array}{c}\text { 期待 } \\
\text { 耐用期間 }\end{array}$ \\
\hline 防せい油 & $\begin{array}{c}\text { 防せい油 } \\
x \text {-カー }\end{array}$ & 油脂類 & 化比 - & $\begin{array}{l}\text { 屋内 } \\
\text { 包装の内部 }\end{array}$ & 月単位 \\
\hline 㳂 装 & $\begin{array}{c}\text { 洤料メーカ- } \\
+ \\
\text { 塗装業者 }\end{array}$ & $\begin{array}{l}\text { 高分子 } \\
\text { 化合物 }\end{array}$ & $\begin{array}{l}\text { 防せい } \\
\text { 顔料 }\end{array}$ & $\begin{array}{l}\text { 大気中 } \\
\text { 海洋巏境 }\end{array}$ & 年単位 \\
\hline ラ㐾ンク & $\begin{array}{l}\text { ラ仁ンタメーカー } \\
(=\text { 施工業者) }\end{array}$ & $\begin{array}{l}\text { 高分子 } \\
\text { 化合物 }\end{array}$ & 強化材 & $\begin{array}{l}\text { 化学装置内面 } \\
\text { 化学工場床面 }\end{array}$ & 年単位 \\
\hline
\end{tabular}

下位の分類に入るべき用語が説明不足のまま用いられて 別種の材料であるかのような印象を受けたり，ラギング のように防音・防振なぞ別の機能材料が防食も兼放得る ために用いられたりすることもある。したがって、ニー ザーが各種材料の本質的特徵を理解し適材を使い分ける ためには，用語の弁別から入らなければならない場合も 多い。

この種の言葉の中で最も注意すべき用語は “ューティ ング”であろう。簡単な和英辞書で「塗装」を引くと最 近刊のものでも painting としか出て来ないが，この言 葉は, 西洋画の伝統を汲む装飾用塗装分野は別として, 少なくとも「ざび止め」以上の防食性能を期待して塗装 する分野ではあまり好ま机ないようで， coating の方が 
最近では多用されている。そして, 海風に曝される橋梁 などで数年以上の塗膜寿命が望まれるような用途に対し ては重防食コーティング 一 - heavy duty coating一 と いら言葉が使われている。一方, 化学装置内面での防食 を主対象とする有機ライニングの分野では，比較的膜厚 の薄い被覆 $\left(500 \mu \mathrm{m}\right.$ 位以下 $\left.{ }^{4}\right)$ を, 高温の酸性液中で耐 え得るものも含めて単にニーティングと称している。両 者の「コーティング」のいずれがより厳しい環境に用い られるか，言葉の上からだけでは区別し難い。

更に付言するならば，塗装分野汇扣いては，規定の年 数が過ぎた時に全塗装面積中で素地金属にさびが発生し ていた面積がある比率以下であることを保証の内容とし ている。その比率がいかに小さくとも, 皮膜に生じる 孔（微細欠陥）はかなりの数が許されることであろう。 それに対し，有機ライニングの分野では，保証期間中は 皮膜に一点の小孔も生じないことが (現実は別として) 期 待されている。

このように，用語といらものはそれぞれの業界で適当 に(製品に重みを付けるために) 使われることもあるの で，言葉だけでなく実態を十分に把握して検討しなけれ ばならない。

\section{2. 有機ライニングの種類と特徵}

\section{1 有機ライニングの分類}

有機ライニング皮膜は，有機高分子である（合成）樹 脂ニプラスチックスが膜としての形態を維持し，その中 に無機あるいは有機の繊維または無機の細粒・細片が皮 膜性能を向上させるべく必要に応じ充填された構成とな っている。それぞれに多くの種類があり，例兄ば同一系 統の樹脂でも分子量や細部の分子構造, 硬化剂の種類, 施工性改良のために加えられる添加剤の種類などによっ て特徵が大きく異なることがある。

皮膜性能が基本的には樹脂によって支配されることは 当然であるが，充填材によっても大きな影響を受ける し, 樹脂や充填材の種類によって適した施工方法がある ので，有機ライニングの分類を考えるためには，表 2 の ような多元的な見方が必要である。

この表の中で強いて多用あるいは注目されているもの を挙げるならば，熱可塑性樹脂ではフッ素樹脂のライニ ング・コーティング, 熱硬化性樹脂では焼付けコーティ ング，同じくフレークライニング，シートによるゴムラ イニングなどがある。

\section{2 樹脂の種類}

樹脂の特徵を考える上での基本は，熱可塑性か熱硬化

表 2 施工方法別に見た有機ライニングの分類

\begin{tabular}{|c|c|c|c|c|c|c|c|c|}
\hline \multirow{2}{*}{\multicolumn{2}{|c|}{ 施工方法 }} & \multirow{2}{*}{$\begin{array}{l}\text { 原料の } \\
\text { 状 態 }\end{array}$} & \multirow{2}{*}{ 強化材 } & \multirow{2}{*}{ 加 熱 } & \multicolumn{3}{|c|}{$\begin{array}{l}\text { 使用される合成樹脂の系 } \\
\text { 統 }\end{array}$} & \multirow{2}{*}{ 满考 } \\
\hline & & & & & $\begin{array}{l}\text { 熟可塑 } \\
\text { 性樹脂 }\end{array}$ & \begin{tabular}{l|} 
熱硬化 \\
性樹脂
\end{tabular} & $\exists \quad \Delta$ & \\
\hline \multirow{3}{*}{\multicolumn{2}{|c|}{$\begin{array}{l}\text { シートライニ } \\
\text { ング }\end{array}$}} & \multirow{3}{*}{ シート } & \multirow{5}{*}{ な し } & 加硫 & & & 0 & 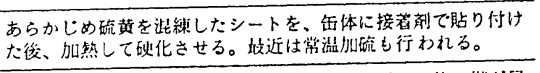 \\
\hline & & & & - & 0 & & & 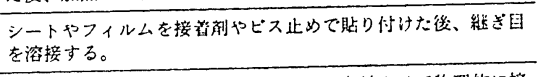 \\
\hline & & & & 加 熱 & 0 & & & $\begin{array}{l}\text { パイプの第合、加热して広げたり、逆に収縮きせて物理的に接 } \\
\text { 合させる劫合もある。 }\end{array}$ \\
\hline \multirow[b]{2}{*}{ 染 } & \multirow{2}{*}{$\begin{array}{l}\text { 主に } \\
\text { はけ、 } \\
\text { スプレー }\end{array}$} & \multirow{5}{*}{ 溶液状 } & & 焼付外 & & 0 & & 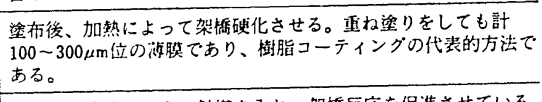 \\
\hline & & & & - & 0 & 0 & & 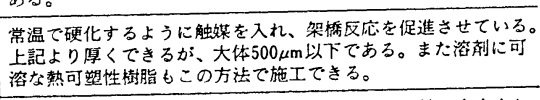 \\
\hline \multirow[b]{2}{*}{ 布 } & \multirow{2}{*}{$\begin{array}{l}\text { 主にロー } \\
\text { ラー、 } \\
\text { こて }\end{array}$} & & 砂 粒 & - & & 0 & & $\begin{array}{l}\text { 硬いけい砂などを入れ耐磨耗性や耐エロージョン性の向上をか } \\
\text { らったもので、樹脂モルタルとして耐摡床材にも用いられる。 }\end{array}$ \\
\hline & & & $\begin{array}{l}\text { ガラス } \\
\text { などの } \\
\text { フレー } \\
\eta\end{array}$ & - & & 0 & & 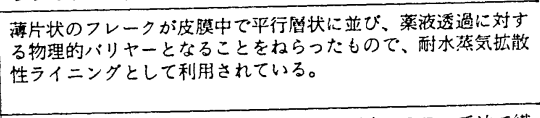 \\
\hline \multicolumn{2}{|c|}{$\begin{array}{l}\text { 䅡曆ライニン } \\
\text { グ(FRPライ } \\
\text { ニング) }\end{array}$} & & $\begin{array}{l}\text { ガラス } \\
\text { などの } \\
\text { 䋳維 }\end{array}$ & - & & 0 & & 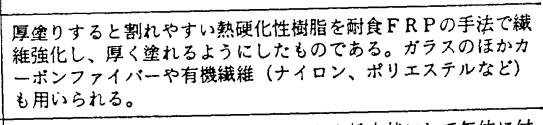 \\
\hline \multirow{3}{*}{$\begin{array}{l}\text { 粉 } \\
\text { 体 } \\
\text { 被 } \\
\text { 覆 }\end{array}$} & $\begin{array}{l}\text { パウダー } \\
\text { スプレー } \\
\text { 法、流動 } \\
\text { 漫漬法 }\end{array}$ & \multirow[t]{2}{*}{ 末 } & \multirow{3}{*}{ な し } & $\begin{array}{l}\text { 母材予 } \\
\text { 熱 }\end{array}$ & 0 & $\begin{array}{l}0 \\
\text { (エポ } \\
\text { キシの } \\
\text { み) }\end{array}$ & & \multirow{3}{*}{ 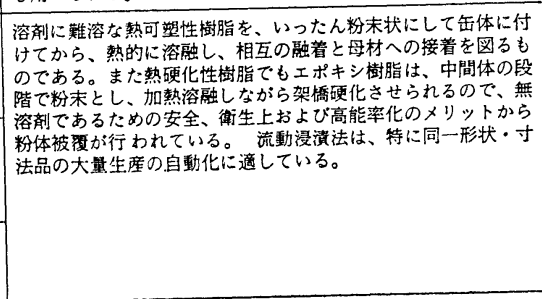 } \\
\hline & 溶 射 法 & & & $\begin{array}{l}\text { 加熱溶 } \\
\text { 虽後吹 } \\
\text { 付け }\end{array}$ & 0 & $\begin{array}{l}0 \\
(\text { エポ } \\
\text { キシの } \\
\text { み) }\end{array}$ & & \\
\hline & $\begin{array}{l}\text { 粉末ディ } \\
\text { スパージ } \\
\text { ヨン法 }\end{array}$ & 锠鹳液 & & $\begin{array}{l}\text { 㘹布後 } \\
\text { 妿熱溶 } \\
\text { 融 }\end{array}$ & 0 & & & \\
\hline
\end{tabular}


性かということである。前者は，系状の高分子が絡み合 い，あるいは部分的に整列（結晶）しているもので，絡 み合いが緩いものは材料全体として容易に曲げることが できる。更に加熱されると系同志の結合が緩み流動する ようになる，つまり軟化する。加熱によって自由に変形 させ得る, 塑性加工し得るといらことから熱可塑性樹脂 といら名前が付いている。ポリ塩化ビニル (PVC), ポリ エチレン (PE) や各種のフッ素樹脂等実用されている樹 脂では, 個々の糸が化学的に安定しており, 材料自身は 耐薬品性の高いものが多い。しかし, 有機溶剤に溶かし て施工することがあるように，糸と系の間に溶剤が入り 込んで糸がほぐれて (膨潤) 軟化しやすいものもある。 また，環境中の小さな分子（水分やガス）が系の間を通 り抜け，ライニング皮膜と母材金属との間に透過した物 質がたまって皮膜の膨れや母材の腐食を引き起こすこと もあるので，皮膜単独の耐薬品性だけでの評価はできな い。

熱硬化性樹脂は，フェノール樹脂 (PF) やエポキシ樹 脂 (EP), 不飽和ポリエステル樹脂 (UP), ビニルェステ ル樹脂 (VE) などが広く実用されている。高分子の系が 硬化剂という短い分子で点々と結び合わされ(架橋), 全 体として立体的な網状の構造となっているため, 糸同志 が動き難くなっている(つまり硬い)。加熱されると， 硬化し終わった部分では分子運動が激しくなる分だけ少 し軟らかくなるはずであるが，一般には未反応の硬化剂 が更に架橋し硬化が進行する。加熱を続けると，溶けず に硬いままで最後には炭化・燃焼してしまう。したがっ て，原料汇硬化剂が入りいったん反応が進及出すと変形 させることは一般にはできない。立体構造であるため環 境剂中の低分子体が透過し難い点ではライニング用に向 いているとも言えるが，薬品や酸化剤によって架橋部分 が壞される (分解) こともある。

ゴムは，硫黄を硬化剤とし（加硫剤という）立体的な 網状の構造となっている点で熱硬化性樹脂と似ている が，個々の系が多数の折れ曲がり点を持ち，そこを中心 に回転し変形に耐兄るため全体としてゴム弾性を持って いる。しかし，硫黄を多量に入れ加硫を進めた硬質ゴム は，エボナイトとも呼ばれるように，エポキシ樹脂など に匹敵するほどの硬さがある。

\section{3. 有機ライニングの使用事例}

\section{1 アンケート調查結果}

化学装置などを対象とする有機・無機材料等の使用状 況のアンケート調查は, これまで石油学会, 日本材料学 会, 化学工学協会などで繰返し行われてきたが，目下最 大・最新の調查は ' 82 年 12 月飞発表された化学工学協 会の使用実績調査集 5 ) である。また，これを補足するも
のとして，フッ素樹脂だけを対象に取り上げた使用実績 調查集 ${ }^{6)}$ が'85 年 9 月に発表されている。ここでは前 者の概要を紹介しょう。調査は材料の仕様, 使用環境, 損傷の有無・程度, 使用後の評価などかなり詳細にわた ったが，ニーザー 67 社 90 事業所から 1,115 件の回答 が得られている。これらの中で，使用期間が 2 年未満で 損傷を生じていないもの（評価未定のもの）や主要項目 の記入が不完全であった若干の回答を除き，解析に耐兄 得るものの合計 788 (内, 有機 561) 件が調査集に表示 されている。

有機材料の内, 樹脂系では 403 件中 (単体以外の) 被 覆が 234 件, ゴム系では 154 件中 149 件が被覆であ る。使用環境は酸, 中性塩, 有機溶剤, 排ガス, 純水な ど多岐にわたっているが，有機被覆で損傷を生じたとの 回答は全部で 206 件であった。損傷理由の中で，施工不 良とするものが $35.4 \%$ と最も多く, 回答者がユーザー であることを差し引いても，この種の材料では施工が重 要なことを示している。損傷を生じた比率は $53.8 \%$ と 高率であったが，一方総合評価 $\mathrm{A}$ の回答——将来もし同 一機器を作るとしたならばもら一度同じ材料を使用す る—が樹脂系で 144 件 (61.5\%), ゴム系で 93 件 (62.4\%) あり，たと光損傷は生じても他に代替材料がな い場合もあることを示している。

\section{2 有機ライニングの実用例}

アンケート調査から離れて, 実用例のいくつかをトピ ックス的に挙げてみよう。

* 表 3 は, 化学工学協会がフレークライニングの主な メーカーから聴取した適用実績の一覧》である。表 中，排煙脱硫装置への適用については，希硫酸とい ら環境に执いて後述するフレークライニングの耐水 蒸気拡散性を最大限に発揮した用途であり，この種 装置の防食には欠かせない材料となっている。また， 大型貯油タンク底板の内面・油側に対する防食にも 多用されている。ただし，この場合には経済性の向 上や底板の変形への追随性改善などの理由から, 充 填されているフレークガラスの大きさが排煙脱硫装 置用よりも細かくなっているのが普通である。

* 多くの化学薬品用の機器や配管の防食にフッ素樹脂 が広まりつつある。フッ素樹脂の中では 4 フッ化樹 脂（商品名テフロンなど）が有名であるが，耐熱・ 耐薬品性には勝れているるのの残念ながら施工性が 悪く，諸特性を落とさず容易に施工しうるようにす るため多種類のフッ素樹脂が開発されてきた。最 近, このような樹脂の改良と施工技術の向上とが機 器の長寿命化への要求と合致し用途が広がってい る。

*一時, 石油掘削用ドリリングパイプの内面や天然ガ 
表 3 数社に括けるフレークライニングの適用実績

\begin{tabular}{|c|c|c|c|c|c|c|c|}
\hline 道用分野 & $A$ 祉 & B 社 & C 社 & $D$ 社 & $\mathrm{E}$ 社 & $\mathrm{F}$ & 船 考 \\
\hline 化学装䛇一般 & 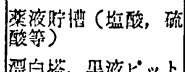 & 校液タンク & 塔輠煩，脱臭塔 & 反応梅，䅉液聍槽 & & 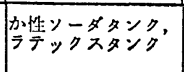 & 通用例多数 \\
\hline 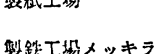 & 筞 & 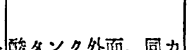 & & & & & \\
\hline 繁涂工场メッキラ & 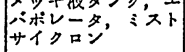 & ー、, クーラー水室 & & & & & \\
\hline 原炎虑液処理站䀴 & 湭嚓渡タンク & 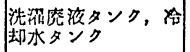 & & & & & \\
\hline LNG タンク & & 外板バリヤ & & & & & \\
\hline 时油タンク & & 各程拧油タンク & 垎程拧油タンク & |各俇拧油タンク & 名程狩油タンク & 各種琮油タンク， & 適用例多数 \\
\hline 純・上・淡水 & & 水・泾水タンク，配 & 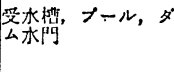 & 水タンク，花架水權 & ボイラ用水タンク & 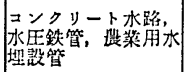 & \\
\hline 下水，排水 & & 下水処理标，同管 & & 水処理用㖟收荅 & 排水タンク & & \\
\hline & & 酎酸ホシンプ林 & 取水管 & & & & \\
\hline 排䂳脱硫装保 & 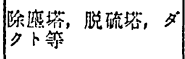 & 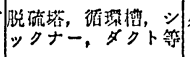 & 我 & ダクト & & & 通用例多数 \\
\hline 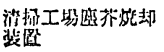 & 命却谷，畍収塔 & & & & & & \\
\hline 集器装通 & 显武コットレル & & 阵朢装卧 & & & & \\
\hline & 煙突 & & 煙笑 & & & & \\
\hline 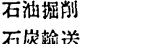 & & & 以r & & & ツレ & \\
\hline $\begin{array}{l}\text { 石孷榆送 } \\
\text { 船舶 }\end{array}$ & & タミカルタンカー & lonth & & & シッット & \\
\hline 船船 & & 水海船外板，デッキ & & & & 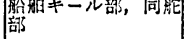 & \\
\hline 海洋巏造物 & & 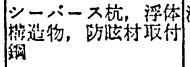 & 知洋嘞造物 & & & 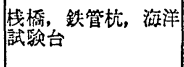 & \\
\hline 橋梁 & & 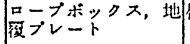 & & & & 橋澡 & \\
\hline 鈛骨 & & & 建家鉄骨，架落 & & & & \\
\hline
\end{tabular}

ス用ラインパイプの内面へのエポキシ(フェノール) 樹脂のコーティングが日本であかなり行われていた ことがあるが，最近は少し下火のようである。

*先のアンケート調查の中でも, 実はコンクリート槽 に施工した例が 10 件含まれていたのであるが，最 近ではコンクリートクライシスに端を発して，土 木・建築分野に括ける鉄筋コンクリートへの樹脂 イニングが注目され，業界でも研究会が持たれてい る。

*また土木・建築分野では，特殊なライニング技術の 一種といらべきであろうが，屋外やビル内の各種配 管内面の補修用にプラスチックパイプの挿入やエポ キシコーティングが現場で施工されるようになって 来ている。ただし，小口径の屈曲した配管への現場 施工は，まだ全面無欠陥で施工するところまでは至 っていないように見受けられる。

\section{4. 有機ライニング選定の考え方}

\section{1 選定上考慮すべき外的条件}

樹脂ライニング工業会では，最近「樹脂ライニングの 工事費積算指針 PLA-R-301-88」を発表したが，その中 で樹脂ライニング工事の見積仕様書作成に必要な項目を 表示している。列記された諸項目の前半が，ライニング の仕様（と価格）を決定する条件となるわけであるか ら，その部分のみを抜粋して表4 亿示した。
表 4 樹脂ライニング見積時に必要とされる項目

\begin{tabular}{|c|c|c|c|}
\hline 目 & & 適 & コストとの関係 \\
\hline 1. 概 要 & \multicolumn{2}{|c|}{ 施工の目的 } & \multirow[b]{3}{*}{ 工事原価全般 } \\
\hline \multirow{5}{*}{$\begin{array}{l}\text { 2.施工対象 } \\
\text { 物件 }\end{array}$} & \multirow{5}{*}{\multicolumn{2}{|c|}{$\begin{array}{ll}2-1 . & \text { 機器の名称 } \\
2-2 . & \text { 缶体の材質、形状、寸法 } \\
2-3 . & \text { 部材の明細 } \\
2-4 . & \text { マンホール、ノズル類の明細 } \\
2-5 . & \text { 新設または旧設. } \\
& \text { (旧設の場合、その状態 ) }\end{array}$}} & \\
\hline & & & \\
\hline & & & 全 \\
\hline & & & 众 \\
\hline & & & 众 \\
\hline \multirow[t]{7}{*}{ 3. 使用条件 } & 提示項目 & 提 示 内 & \multirow{7}{*}{ 保証コスト } \\
\hline & $\begin{array}{l}\text { 使用液体 } \\
\text { ガ } \quad \text { ス }\end{array}$ & 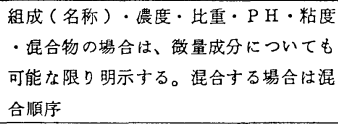 & \\
\hline & 度 & $\begin{array}{l}\text { 常用、最高、最低、温度変化・及び加熱 } \\
\text { 方法 (自己発熱、シャケット、直火、湯 } \\
\text { または油浴、蒸気吹き込み、ホ、ダウサ } \\
\text { ム、ブライン・等の区別) }\end{array}$ & \\
\hline & 圧力 & $\begin{array}{l}\text { 加圧・减圧の度合いと使用時の変化及び } \\
\text { その頻度 }\end{array}$ & \\
\hline & $\begin{array}{l}\text { 固形物の } \\
\text { 有 無 }\end{array}$ & 固形物の種類、粒径 & \\
\hline & $\begin{array}{l}\text { 流 動 } \\
\text { かきまぜ }\end{array}$ & 流動する場合の流速、かきまぜ方法 & \\
\hline & 特記事項 & 運転上の特記事項 & \\
\hline 4 施工場所 & \multicolumn{2}{|c|}{$\begin{array}{l}\text { 地理的環境条件 } \\
\text { 作業場環境条件 }\end{array}$} & 工事原価全般 \\
\hline 5 納 & \multicolumn{2}{|c|}{$\begin{array}{l}\text { 工事期間（工程表別途作成） } \\
\text { 市期、気温 }\end{array}$} & 工事原価全般 \\
\hline
\end{tabular}

沢山の項目があるように見觉るが，これでも它しろ足 りない位であり，筆者は後述する水蒸気拡散の観点から 機器外面の保温の有無, 設置場所が屋内か屋外か（雨が 
かかるかどうか) 等も重要な事項と考えている。また， 通常の材料選定に怙いては第 3 項の使用条件のみが取り 上げられがちであるが，施工の目的（防食のほか，内容 物の付着防止など) や機器の形状・状態, 施工場所, 工 事時期なども勘案しなければならない点を注 意された い。これら条件によって，材質と密接な関係を持つライ ニングの施工方法が制限されることるあるわけである。

しかし，本稿でこれらの全般を説明する余裕はないの で, 樹脂ライニングを使用する上で必要な特性について の概要のみを以下に述べることとする。

\section{2 選定上考慮すべきライニングの特性}

\section{(1) 耐薬品性}

防食を目的とするライニング皮膜が環境剂によって劣 化するかどうかを示す特性である。劣化は, 表面の接液 部から徐々に内部に向かって進行することもあるが，皮 膜内部への環境成分の浸透が早く層全体が劣化する場合 むある。損傷の形態としては, 変色, 軟化・膨潤, 硬化・ 脆化，らくれ，割れなどがある。また，金属で見られる 現象と表面的汇似たものとして, 応力之特定の環境剂之 の相互作用により皮膜に割れ（その前兆で細かなひび状 に見えるものをクレーズという）の入る ESC（環境応 力き裂）や，塩素環境中で使用した際表面に強固な劣化 層ができて以後の環境剤の浸透から皮膜を守る一種の保 護皮膜が形成されるといった現象も見られる。

（2）耐熱性

カタログなどの資料に示されている耐熱温度とは, 単 に空気中で熱だけが加わっている場合のものであって, 薬液にさらされたり長時間にわたって応力がかかってい たり (クリープ)すれば使用温度は当然低下する。ま た，急激な加熱・冷却（サーマルショック）の繰返しに よって, より低温でも剝離や割れを起こすことがある。

（3）耐水蒸気拡散性

水蒸気拡散 ${ }^{8)}$ とは, 有機質の皮膜の両側々温度差（温 度勾配）がある場合，皮膜中での水分の拡散速度が，高 温側から低温側に向かって加速される現象である。内容 物が高温で外面が冷えている機器の内面側に被覆される ことが多く，乙かも透過してきた水分が母材金属汇遮ら れて接着界面にたまらざるをえないため，有機ライニン グにとっては大きな問題である。水溶液の濃度が薄いほ ぞ顕著であり, また, 高温側の温度が高く, かつ両面の 温度差が大きいほど拡散が起こりやすい。ライニング皮 膜と母材との接着力が大きければ，また，皮膜の膜厚が 厚ければ水蒸気拡散汶対する抵抗性は高い。

表 2 の中に, 薄片状のフレークを充填したライニング を揭げて扔いたが，これは図 1 亿示した原理によって耐 水蒸気拡散性を向上させているものであり, この種の皮 膜構成を持ったものをフレークライニングという。フレ

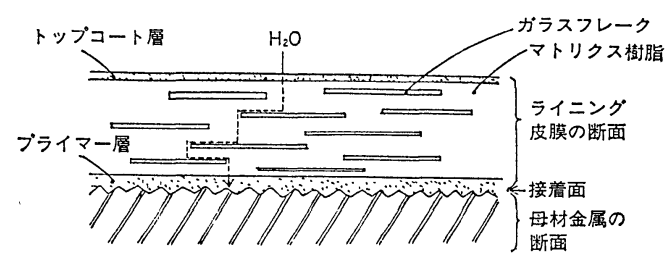

図 1 レフーク混入による効果の概念図

表 5 ガラスフレークライニングの性能に影響する 主な因子

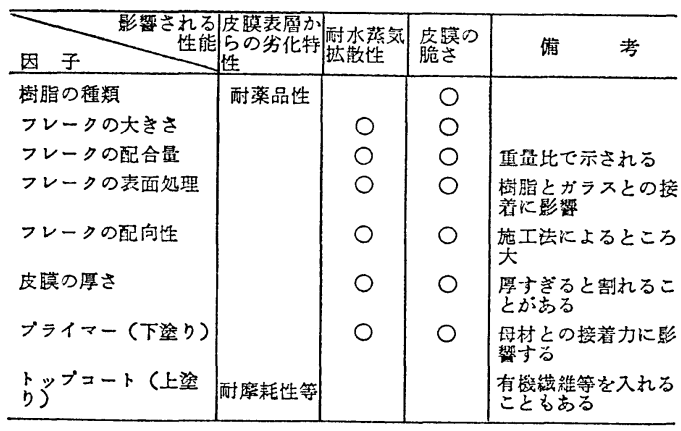

一クの材質にはガラスが最も多用されているが，カーボ ン, ステンレス鋼, 雲母等も利用されている。銀ペンと 呼ばれたアルミニウムペイントや自動車のメタリック塗 装, 防錆用の MIO 塗料なども考え方の上では共通と言 っても良い。ガラスフレークを用いたライニングの性能 に影響する因子を表 5 に示したように，単にフレークラ イニングと言っても, 多様なグレードのものがあり得る ので, 環境の苛酷さと経済性とに応じた適正な選定を行 う助けとなるよう, 化学工学協会化学装置材料委員会に より「フレークライニングの品質表示に関する指針」が 制定され，解説と共に発表7)されている。

(4) 接着性

通常のライニングは，母材と接着していることが前提 であり, 剝離していると熱雪みなどによる変形が機器の コーナーやフランジなどの拘束部に集中し, 皮膜の割れ を起こしやすい。接着力を高めるには, 皮膜形成時の第 一層 (プライマー, 下塗り) には, 表面張力が小さく母 材の表面をよく濡らす液を用いることが基本である。ま た母材表面は，鉄さびや油などの污れを充分除去し（清 浄度・除錆率を高め)，表面に凹凸を付けること（粗面 化）が有効とされている。そのために，ライニング施工 時の素地調整としては，研削材（硬い粒子）を高速で表 面にぶつけるブラスト処理を行らことが一般的である。 ブラストした鋼板の断面の一例を図 2 に示した。

接着力は, 水蒸気拡散やその他の皮膜の劣化によって 低下する。一方, 接着力に対抗する皮膜内部の力（筆者 


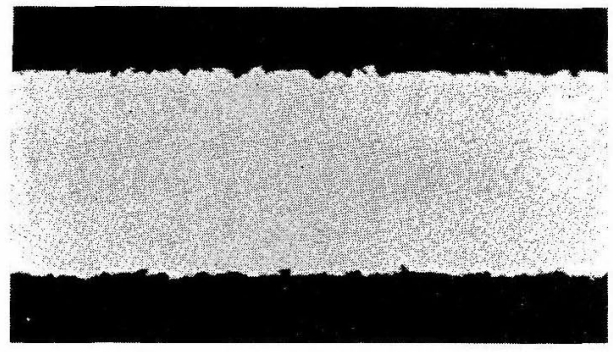

図 2 ブラストした鋼板の断面の例 $(10 \times)$

は剥離力と称している）は, 皮膜形成時の樹脂の硬化収 縮や皮膜と母材との熱膨張の差によって生じるが，その 力は皮膜の弾性率が高い場合は膜厚飞ほぼ比例するた め, 硬い皮膜を厚く施工し過ぎると剥離や割れを生じや すくなる。膜厚が薄いと耐薬品珄上不安があるとして最 小膜厚の規定は良く行われるのであるが，このような皮 膜では最大膜厚の管理も重要である。

(5) 機珹的性質

ライニング皮膜は強度部材ではないが, 機器の輸送・ 据付時や液の流動などの外力に耐えるためには，ある程 度の強度が必要である。摩耗に詨しては, 皮膜中に砂な どの硬い粒を入れ抵抗させる場合が多いが，逆に軟質ゴ ムを厚くライニングし，流体中の粒子の衝突エネルギー を吸收させる方が有効なこともある。硬くとも脆い皮膜 は，母材の局部的な变形に追随し切れず割れてしまいや すいので，注意しなければならない。

\section{3 有機ライニングの選定法}

ライニング皮膜を構成している樹脂そのものの選定の 第一歩は, たと觉ば NACE (National Association of Corrosion Engineers 米国腐食技術者協会) で刊行した Corrosion Data Survey-Nonmetals Section などの 耐食性で行うが，これらは樹脂の配合や充媜物の入り方 などまで細かく規定はされていない。ライニングメーカ 一の耐食表は, その点, 自社のブレンドでテストをして いるはずなので，やや現実に近いと言えよう。しかし一 般的にこ北らは，ビーカーテストのような単純な試験で の結果が多く，もちろんそれは選定の基本として必須な のではあるが，それらは液の組成・温度変化・温度勾 配・流動など、試験条件が実装置に比べて単純に過ぎる ので，耐食表だけで材料を決定することに危険である。

そのため，類似装置や環境下での実績例——前述のア ソケート調査結果など——を調べて候補材料を絞り, メ 一カーと打ち合わせの上，必要に応じて浸漬試験を行 う。その際は, 温度勾配や液の流動・更新など実機の条 件にできるだけ近付けた試験方法を考案する。例衤ば， 試駼板に温度勾配を与えるための装置として良く知られ ているのは，図了に示したよらなるので，これはNACE

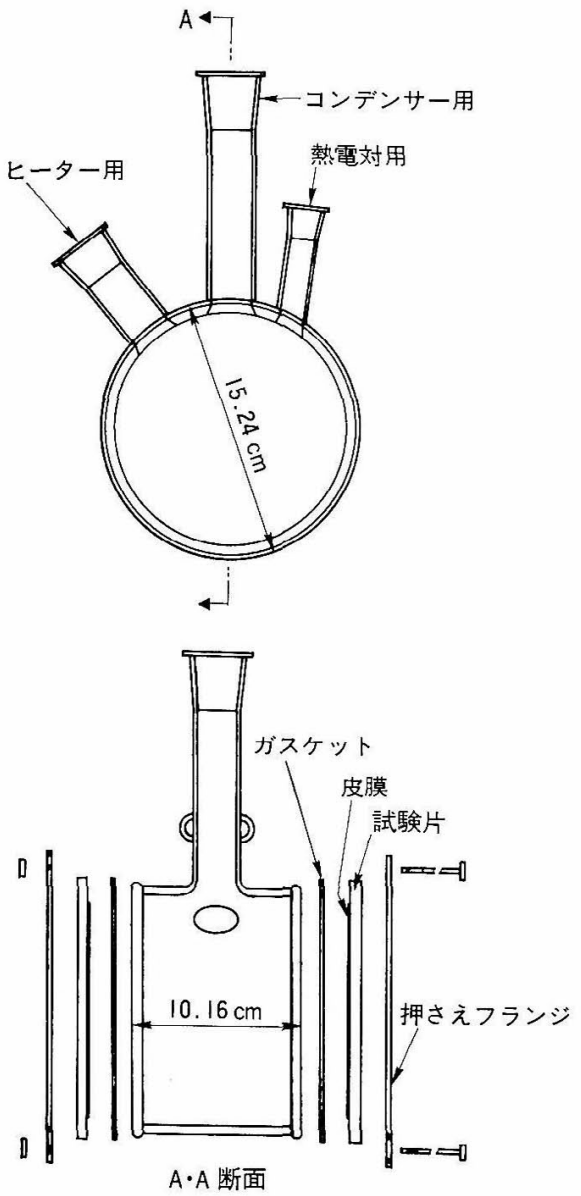

図 3 NACE TM-01-74 万式の水蒸気拡散試験器

で指針 TM-01-74 として定められている。ただし，こ の方式では，温度差を大きく与えようとして試駼板の外 面を水冷するとヒーターの熱容量が足りず，また 1 装置 で2枚の試験しかできないので，各実験者によって様々 な装置が工夫され ${ }^{9 /, 10)}$ 利用されている。な扮ここれらを 踏まえて樹脂ライニング工業会では，一昨年「樹脂ライ ニング皮膜への環境剂の 浸透性試験方法に関する基準 PLA-R-106-86」を制定している。

更に実装置の内部に試験片を装着すれば，より信頼で きるデータが得られることとなるが，ここまで進むと一 般には多種類の材料を供試材とするかけに行かず，試験 回数も限定されるので試験片をより一層慎重に選ばなく てはならない。なお，単て機器内部に試験片を入れたた けでは奉機の壁面と同様の温度勾配や液の流動を与兄る ことは実際には困難である。また，機器の内部でも局部 的な環境条件の差の大きいことが多いので注意しなけれ ばならない。対象材料にかなり自信が持てる段階となっ たならば，マンホールカバーや配管の一部に試験施工し て最終確認を行う場合もある。 
これらの過程を通じて実際上気を付けねばならないこ とは, 対象とする供試材が, 品種・品番だけでなく, 試 験片の作り方（素地調整の程度, 膜厚, 乾燥 - 加熱条件 等）まで含めて，それを採用して施工する時の諸条件と どの程度合致しているかといらことである。合致するの は当たり前だと簡単に言いきれれば良いのであるが，ラ イニングの種類によってはかなり難しい場合もある。

\section{5. 有機ライニングの施工管理と検査}

\section{1 有機ライニングの作業工程}

金属材料による機器製作が精練・圧延・製缶・溶接の 諸工程に分化しているのに比べて，シートライニング以 外の有機ライニングでは, 液状の未反応樹脂から皮膜形 成・硬化までの全工程が施工業者の手だけによって作業 されるため, 施工の良否がその性能に極めて大きく影響 する。この点は前記の使用実績の項でも紹介した通りで ある。ライニングの施工がどのように行われるかを理解 する一助として, フレークライニングの作業工程 ${ }^{11)} の フ$ ローの一例を図 4 に示した。他の諸工事之はかなり異な った作業が多いので，ニーザー側担当者として種々の問 題はあろらが，施工管理と検查とはできるだけ十分に行 らよう努めるべきである。

\section{2 有機ライニングの施工管理}

施工管理のポイントは, 施工される機器 (缶体) の仕 上げ，原料の品質と保管法, 素地調整としてのブラスト の作業条件 (研削材の種類・使用量・衝突エネルギー), 原料の調合法之使用量, 皮膜形成作業法, 硬化条件維持 法のそれぞれが適切かどうかということである。いずれ も重要な事項であるが，中でもブラストの良否 ${ }^{12), 13)}$ は ライニングの寿命を大きく左右すると言われている。污
れ作業でありまた次に続く塗布作業との間に時間を置 くことが出来ないので難しい点が多いが，最重点項目と して組取むべき項目である。このブラストの作業及び検 查方法について, 現在 ISO で国際規格作り年)が進んで いる。また全作業を通じて, 気温・湿度・母材の表面温 度を測定し, 結露条件下での作業を避けるょうにしなけ

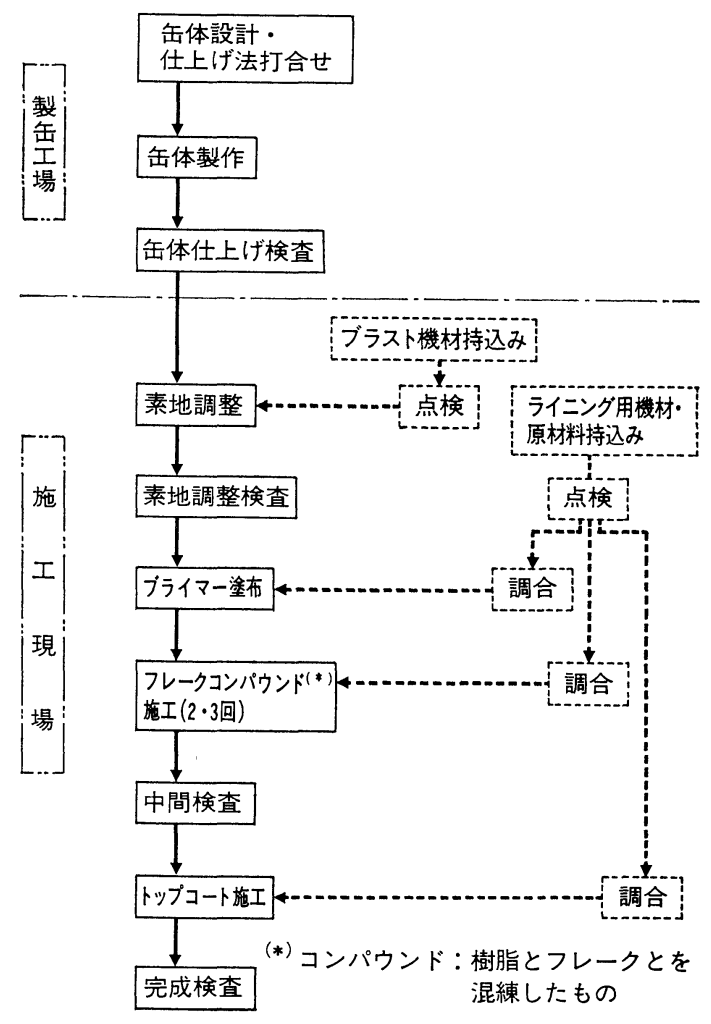

図 4 フレークライニングの作業工程の例

表 6 有機ライニング施工時の検査項目

\begin{tabular}{|c|c|c|c|}
\hline & \multirow{2}{*}{ 查 事 項 } & \multicolumn{2}{|l|}{ 検 } \\
\hline & & 非 破 壊 的 検 查 & 破 壊 的 検 查 \\
\hline \multicolumn{2}{|c|}{ 缶体仕上げ } & $\begin{array}{l}\text { 寸法(とくに開口部・死角部の確認)、表面㾟、角・隅部の R、溶接ビ } \\
\text { ードの平滑さ・ブローホール }\end{array}$ & \\
\hline \multicolumn{2}{|c|}{ 下 地 処 理 } & 面粗さ、除錆率、残留物 & 残留物の分析、切断断面 \\
\hline \multirow{2}{*}{$\begin{array}{l}\text { 原 } \\
\text { 料 }\end{array}$} & 澍脂·硬化剂 & ラベル(名称、製造番号·年月日)、分離·沈澱·照濁状況、比重、粘度 & 硬化試験(時間、硬さ、色)、分子量等の分析 \\
\hline & 強 化 材 & ラベル、梱包状態、寸法、単位重量、污れ、織り方、塊・しわ等の久宿 & \\
\hline \multicolumn{2}{|c|}{ 皮膜形成作業 } & 気温、湿度、污染、原材料使用状況、標準作業 (混合·含浸·脱泡等)の監視 & \\
\hline \multirow{2}{*}{ 完 } & 観 & 色、つや、だれ、割れ、気泡、含浸不良 & \\
\hline & さ & 磁力式厚さ計、渦電流式厚さ計 & 切断断面 \\
\hline \multirow[t]{2}{*}{ 成 } & さे & & 押込式硬さ計 \\
\hline & 剝離程 度 & 打診、超音波厚さ計 & 接着力、接着面の状態 \\
\hline \multirow[t]{2}{*}{ 膜 } & ピンホール & 湿式(電気抵抗式等)、乾式(放電式) & 欠陷部切出し \\
\hline & 別製試験片 & & 強度、積層状態、重合度 \\
\hline \multicolumn{2}{|c|}{$\begin{array}{l}\text { 輸送・据付け、 } \\
\text { 組立て作業 }\end{array}$} & 割れ、凹み & \\
\hline
\end{tabular}


表 7 樹脂ライニング工業会制定の検査関係基準書 リスト

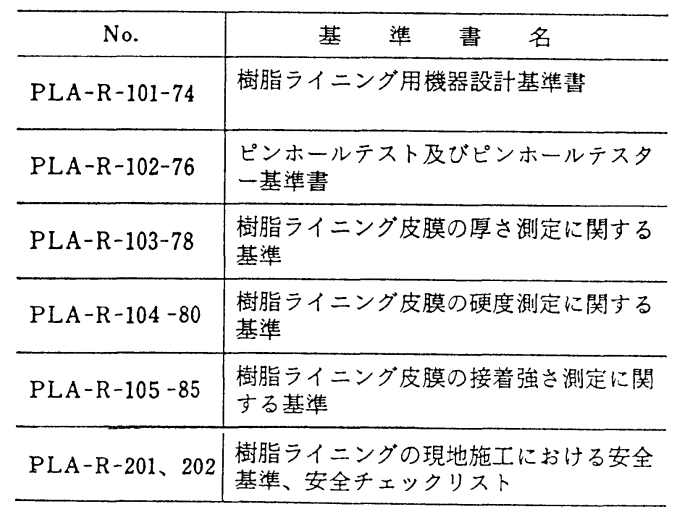

ればならない。更にライニング用原料は, 可燃物・有機 溶剤を含んでいるものが多いので, 安全衛生上も充分な 配慮が必要である。

\section{3 有機ライニングの検查}

各工程に打沙査については, その一覧を表 6 に示 したが，これらをより詳細に説明した指針が化学工学協 会化学装置材料委員会より発表されている防ので参照さ れたい。な技，これらの中で重要ないくつかの項目につ いては, 表 7 のごとく樹脂ライニング工業会により基準 書が制定されているので，それに従うと良い。

表 6 中の完成検査について若干補足説明しておきたい ことがある。まず, 硬さの測定は, 針の先端を皮膜中に 押し込んだ時の抵抗の大小で測定されるものなので, ラ イニングのように薄い皮膜の場合は破壞検査になってし
まらといらことである。したがって, 肝心の接液面を避 ケ，ガスケット当たり面の外側や別の試験片で測定せざ るを得ない。

ピンホールテストについては言うべきことが特に多い が15), ここではピンホールテスターにも沢山の種類があ ることを表 8 として揭げると共に，これらのいずれを用 いても残念ながら「有機ライニングにとって使用上有害 となり得る皮膜の微小開口部のすべてを検出することは 不可能である」ということを述べて执きたい。したがっ て，有機ライニングの品質は，このような特定の検査だ けによって保証されるものではなく, 適切なライニング 仕様を前提として, 全般的施工管理や一連の検査を総合 することによってはじめて良いものになるということを 銘記して特かなくてはならない。

\section{6. 使用開始後の診断}

機器の運転中に有機ライニングの劣化を診断する方法 は，まだほとんど実用化されていない。皮膜中への薬液 の浸透を電気特性の变化としてとらえる方法 ${ }^{16)}$ や，皮膜 に割れ・ふくれが生じると壁温が変化するであろらこと を利用し外部から機器の壁の温度分布や変化を測る方法 などが考えられている。

運転停止時には，外観検査を中心に表 6 の一連の手法 が適用される。外観検査は，変色・ふくれ・割れなどを 調べるものであり, 新品のサンプル板との比較や 30 倍 程度の拡大鏡での観察を含めれば，有益な様々の情報を 得ることができるので，決して軽視すべきではない。

最近, 非破壞検査の有力な手法として, 超音波によっ

表 8 ピンホールテスト方式（及びテスター）の分類

\begin{tabular}{|c|c|c|c|}
\hline \multicolumn{2}{|c|}{ 方式 } & 理 & 特 \\
\hline \multicolumn{2}{|c|}{ 浸 沾 式 } & 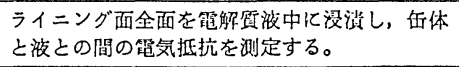 & $\begin{array}{l}\text { 実際の使用状態に近いテストだが，導通部（欠 } \\
\text { 陌）を見つけて補修するのが困難。 }\end{array}$ \\
\hline 湿 & 化 学 式 & 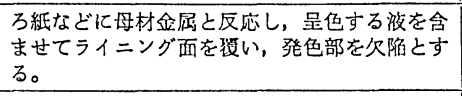 & 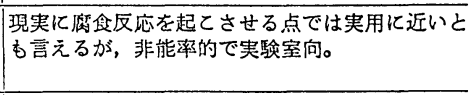 \\
\hline 式 & 電気抵抗式 & 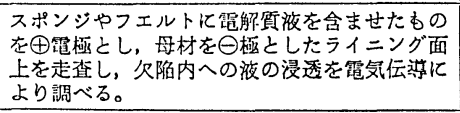 & 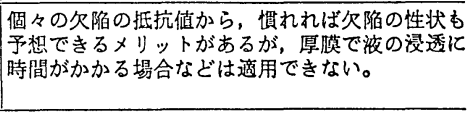 \\
\hline \multirow[t]{5}{*}{ 乾 } & 式 & 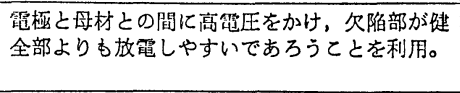 & 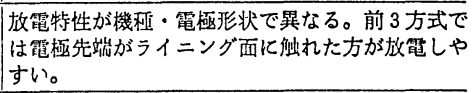 \\
\hline & 直流放電式 & 㨁流に整流し印加している。 & $\begin{array}{l}\text { 䨌圧が設定しやすい。装䇛が大型となる。テスト } \\
\text { 中皮膜面に静電気が带電しやすい。 }\end{array}$ \\
\hline & 交流放電式 & $\begin{array}{l}\text { 交流電源からインダクションコイルで昇圧, 印 } \\
\text { 加する。 }\end{array}$ & 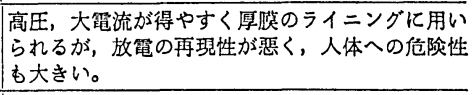 \\
\hline & パルス式 & 間欠的にパルス䉓王を印加する。 & 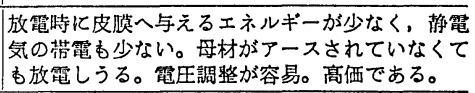 \\
\hline & 火花発振式 & $\begin{array}{l}\text { テスラーコイルにより常時コロナ放露してお } \\
\text { り、久陷があるとそとにコロが集中する。 }\end{array}$ & 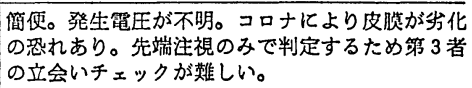 \\
\hline
\end{tabular}


て，剥離の有無だけでなく，残存している接着力そのも のを測定し得る方法 ${ }^{17)}$ が発表された。従来のように周波 数を固定して測るのではなく, 周波数を連続変化させつ つ接着界面での共振が最大となるような周波数の値を求 め評価するものである。個々のライニングについてのバ ックデータ（検量線）が必要であるが，それを作れば極 めて強力な武器になるものと期待されている。

非破壞検查で異状が認められたならば，その部分を剝 離もしくは母材ごと切断し, 破壊検査を行うことが望ま しい。皮膜の硬さ - 強度 - 接着力の測定や, 断面の顕微 鏡・SEM（走査型電子顕微鏡）・EPMA（電子プローブ マイクロアナライザー) 等による観察・分析などを行う ことによって，劣化・損傷の原因追及や対策立案が可能 となる ${ }^{18}$ 場合が多い。 (1988 年 5 月 23 日受理)

\section{文献}

1）青木 茂：防食技術，33，284 (1984)。

2）青木 茂：防食技術，33，520 (1984).
3) 青木 茂: Petrotech., 5, 1042 (1982).

4) 青木 茂: 防錆管理, 26, 21 (1982).

5) 化学工学協会化学装置材料委員会編：化学装置用 非金属材料と使用実績データ集 (1982).

6）化学工学協会化学装置材料委員会編：製作・施工 時の検查指針と弗素樹脂使用実績データ集(1985).

7) 青木 茂: 化学工学, 48, 692 (1984).

8）井口高行, 奥田 聰：金属表面技術, 24, 522 (1973).

9）青木 茂：配管技術，21，[10] 110 (1979).

10）冨川水門，戸河里脩：防錆管理，32，4 (1988).

11）青木 茂：配管技術，29，[15] 176 (1987)

12）青木 茂：塗装技術，21，[2] 69 (1982).

13）青木 茂：塗装技術，21，[11] 195 (1982).

14）青木 茂: 防錆管理, 31, 89 (1987).

15）青木 茂：金属表面技術協会ライニング評価技術 専門部会第 3 回例会資料, (1987).

16）富川水門，工藤喜代孝：材料学会腐食防食部門委 資料, No. 113, Part 2, 41 (1983).

17) 㺫崎博信：化学工学協会第 53 年会予稿集 (1988).

18）青木 茂：材料学会腐食防食部門委資料, No. 85,45 (1978). 